\title{
АКАДЕМИЧНО РАЗВИТИЕ
}

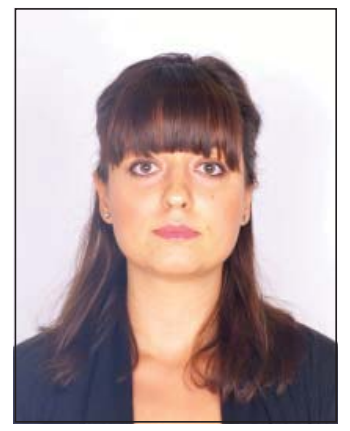

\section{ЗАЩИТА НА ДИСЕРТАЦИЯ}

На 06.06.2016 г. в МУ - Варна се състоя Официалната защита на дисертационен труд за присъждане на образователна и научна степен „ДОКТОР“ по научна специалност Офталмология на Д-Р ЕЛИЦА ГЕРЧЕВА ХРИСТОВА, на тема „Микроструктурни характеристики на промените в макулата при заболявания на ретината със социално значение 6

\section{Научен ръководител: Доц. Д-р Зорница Златарова д.м.}

\section{Научно жури:}

Проф. д-р Христина Групчева, д.м.н.

Проф. д-р.. Ива Петкова, д.м.

Доц. д-р Виолета Чернодринска, д.м.

Доц. д-р Геновева Алексиева, д.м.

Доц. д-р Зорница Златарова - Ангелова, д.м.

\section{Председател: Проф. д-р Христина Групчева, д.м \\ Рецензенти: \\ Проф. д-р Ива Петкова, д.м. \\ Проф. д-р Христина Групчева, д.м.н.}

Останалите членове на журито със становища.

С пълно единодушие, с 5 гласа „ДА“ на д-р Елица Герчева Христова беше присъдена образователна и научна степен „ДОКТОР“.

\section{Резюме}

Целта на настоящата дисертационна работа е да се изследват микроструктурните промени в макулата при заболявания на ретината със социално значение и да се съпостави диагностичната стойност на ОСТ и ФА при тези заболявания.

В настоящото проучване са включени общо 293 пациента ( 417 очи), разделени в две големи групи. Група I - контролна група, състояща се от 102 индивида (200 очи) на средна възраст $44,7 \pm 18,5$ г. (от 16 до 82г), от които 48 мъже и 54 жени. Контролната група бе съставена от здрави доброволци, без системни или очни заболявания, нетретирани оперативно и/или медикаментозно с $\mathrm{BCVA} \geq 1.0$. Всички участници в нея са изследвани с 3D OCT-2000Topcon. Група с патологични промени в ретината, като очите от тази група са разделени на следните подгрупи: група II A - 60 очи на 50 индивида със суха форма на макулна дегенерация свързана с възрастта; група II Б - 55 очи на 50 индивида с ексудативна форма на макулна дегенерация свързана с възрастта; група III - 51 очи на 50 индивида с оклузия на v. centralis retinae (от тях 
42 с клонова оклузия и 9 със стволова оклузия на ВЦР) и група IV - 51 очи на 41 индивида с централен серозен хориоретинит.

Установи се, че ретиналната дебелина и обем при здрави очи имат връзка с възрастта, но не и с пола. Макулната дебелина е най-голяма във възрастта от 30 до 50г., като след това тя бавно намалява. Намаляването на ретиналната дебелина е с $0.150 \mu \mathrm{m}$ за една година.

Статистически значимо по-малка ретинална дебелина, във вътрешния 3 мм ринг по ETDRS, средната, централната ретинална дебелина и обем се наблюдаваха при пациенти със суха форма на МДСВ в сравнение със здравата контролна група. Разлика в макулната дебелина, между здрави пациенти и такива с ексудативна МДСВ, се установи само за фовея и ЦРД, което показва, че ексудативната форма засяга централните части на макулата. Статистически значима разлика между пациентите със суха и ексудативна форма на МДСВ имаше както за фовея, назалните пара- и перифовеоларни полета, така и за централната ретинална дебелина и обем.

Статистически значимо по-голяма ретинална дебелина във всички изследвани ETDRS зони имаха пациентите с клонова оклузия на ВЦР в сравнение с контролната група здрави доброволци. Аналогични бяха и резултатите от сравнителния анализ между пациентите със стволова оклузия и нормалните контроли с изключение на ЦРД. Що се отнася до статистически значима разлика в ретиналната дебелина и обем между пациентите със стволова и клонова оклузия на ВЦР, то такава беше установена само за долната перифовеоларна зона.

Статистически значими разлики в дебелината на ретината между пациентите с ЦСХ и здравата контролна група се установиха за всички ETDRS зони с изключение на долната и темпоралната перифовеоларни зони, както и за средната и централната дебелина в макулата и средния обем в макулата.

Установи се умерена статистически значима негативна корелация между зрителната острота на пациентите със суха форма на МДСВ и промените настъпващи в IS/OS и ELM на OCT.

При пациентите с ексудативна форма на МДСВ наличието на интрареетинални кисти във вътрешните ретинални слоеве оказва сериозно влияние върху зрителната острота. Установихме, че с най-ниска начална 30 са пациентите с дифузен ретинален едем и отлепване на ПЕР.

При пациентите с оклузия на ВЦР негативна корелация между зрителната острота и промените настьпващи в макулата имаше за линията изобразяваща връзката между IS/OS и серозното отлепване на невросензориума.

При ЦСХ, най-сериозно влияние върху зрителната острота имаше диаметъра и височината на серозното отлепване невросензориума.

Оптичната кохерентна томография е придобила сериозна популярност при откриването на макулни промени характерни за редица ретинални заболявания. Методът е безопасен, неинвазивен, високоскоростен и предоставящ обективна информация за фовеалната и ретиналната морфология. В някои практики, ОСТ е алтернатива на ФА при проследяването на патологичните промени в ретината. Въпреки добрата съпоставимост между ОСТ и ФА, всеки един от тях има предимство по отношение на конкретни патологични промени пред другия. Този факт обуславя и необходимостта от анализирането на резултатите от двете методики при оценка на ретиналните заболявания и преди предприемане на терапия. 
Конференции, симпозиуми, конгреси Conferences, Symposia, Congresses

Български офталмологичен преглед брой 3, 2016(59) Bulgarian review of ophthalmology

\section{Уважаеми колеги и приятели!}

На 15.10.2016г. в Гранд хотел Пловдив (Новотел - Пловдив)

ще се Проведе Поредният 11-ТИ ВИТРЕОРЕТИНАЛЕН СИМПОЗИУМ НА ТЕМА: "ЕВОЛЮЦИЯ ВЪВ ВИТРЕОРЕТИНАЛНАТА ХИРУРГИЯ".

\section{Такса участие}

60 лв.

до 21.09. 2016г.

70 лв. от 22.09. до 12.10.2016г.

100 лв.

на място

\section{Плащане}

Пощенски запис за Ана Захариева Лазарова , секретар на Университетска Очна Клиника, УМБАЛ "Св. Георги", бул."Пещерско шосе"66, 4001 Пловдив тел.: 0888712362

e-mail: ana_lazarova@abv.bg

\section{Настаняване}

Гранд хотел Пловдив

ул. „Златю Бояджиев” 2, Пловдив 4000

$$
\begin{array}{ll}
\text { Единична стая } & -70.00 \text { лв } \\
\text { Двойна стая } & -90.00 \text { лв }
\end{array}
$$

Цената е с включена закуска, туристически данък и $61 \%$ отстьпка от цена рецепция.

За резервация на хотелска стая, моля да се свържете директно с Гранд хотел Пловдив: тел: 032/934 163 или 032/934 136

факс: 032/934 160

e-mail: reservation1@synergonhotels.bg

\section{Краен срок за резервации, промени и анулации 05.10.2016 г.}

През м.септември очаквайте подробна информация за събитието.

С пожелание за хубаво лято! Проф. д-р Нели Сивкова, дм, FЕВО 
B 4-ти брой очаквайте:

\author{
ИДИОПАТИЧНА ИНТРАКРАНИАЛНА ХИПЕРТЕНЗИЯ - \\ ДЬЛГОСРОЧНО ПРОСЛЕДЯВАНЕ НА 6 КЛИНИЧНИ СЛУЧАЯ \\ Колева-Георгиева Д., Атанасов М. , Сивкова Н. 1, Крумова С. , \\ Врабчев С. , Желязков Х.
}

РЕЗУЛТАТИ ОТ ЛЕЧЕНИЕТО НА РЕТИНОПАТИЯ НА НЕДОНОСЕНОСТТА С ЛАЗЕРТЕРАПИЯ В ДЕТСКО ОЧНО ОТДЕЛЕНИЕ НА УМБАЛ „АЛЕКСАНДРОВСКА”

В. Чернодринска, О. Младенов

\author{
ТРАНСПЛАНТАЦИЯ НА ЕХ VIVО РАЗМНОЖЕНИ ЛИМБАЛНИ \\ СТВОЛОВИ КЛЕТКИ ПРИ НЕВРОТРОФИЧНА КЕРАТОПАТИЯ - \\ КЛИНИЧЕН СЛУЧАЙ \\ Христова Р., Здравков Я., Христова М., Танев И.
}

\begin{abstract}
СРАВНЕНИЕ МЕЖДУ ТРАДИЦИОННИ ДВУСТРАННИ И ГОЛЯМА ЕДНОСТРАННА РЕЦЕСИЯ НА ВЬТРЕШЕН ПРАВ МУСКУЛ ПРИ СРЕДНОСТЕПЕННА ЕСОТРОПИЯ Димитрова Г., Михайлова Б.
\end{abstract}
ХИРУРГИЧНО ЛЕЧЕНИЕ НА ПТЕРИГИУМА- ИСТОРИЧЕСКИ ПРЕГЛЕД, СЪВРЕМЕННИ ПОДХОДИ
В. Желева, Л. Войнов, А. Калайджиев

КЪСНА ЛУКСАЦИЯ НА МОНОБЛОК ИНТРАОКУЛАРНИ ЛЕЩИ, ИМПЛАНТИРАНИ В КАПСУЛНИЯ САК

И. Шандурков 